\title{
Distribution, Ethnobotany, Pharmacognosy and Phytoconstituents of Coptis teeta Wall.: A Highly Valued and Threatened Medicinal Plant of Eastern Himalayas
}

\author{
Temin Payum
}

\section{Temin Payum}

Department of Botany, J.N. College, Pasighat, Arunachal Pradesh-791103, INDIA.

\section{Correspondence}

Temin Payum

Department of Botany, J.N.College, Pasighat, East Siang District, Arunachal Pradesh, INDIA.

Phone No: 7308461526

E-mail: teminpayum519@gmail.com

History

- Submission Date: 18-10-2017;

- Review completed: 08-11-2017.

- Accepted Date: 20-11-2017

DOI : 10.5530/pj.2017.6s. 154

Article Available online

http://www.phcogj.com/v9/i6s

Copyright

(C) 2017 Phcog.Net. This is an openaccess article distributed under the terms of the Creative Commons Attribution 4.0 International license.

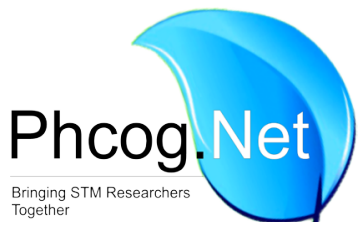

\begin{abstract}
Objectives: To study the distribution, traditional knowledge, dose and preparations, phytoconstituents, pharmacognostic characters and to correlate phytoconstituents and the claimed health benefits among the tribal people of Arunachal Pradesh if any, the present study was carried out. Methods: Field survey and interview were used for ethnobotany and protocol given in Shah and Seth (2010), Kakote et. al.,(2012) and Wallis (2011) was followed to study pharmacognostic studies while GC-MS was used in the studies of phytoconstituents. Results: This study reports numbers of volatile and non-volatile compounds from the rhizome of Coptis teeta with high percentage of berberine alkaloids. The study also reports alkaloid deposition at parenchymatous tissues and vascular tissues of rhizome. Phytoconstituents presents in the ethanolic extract of C.teeta cold be related to health problems and phytoconstituents as claimed by tribal people of Arunachal Pradesh. Conclusion: Locally called Mishmi teeta in Arunachal Pradesh, Coptis teeta Wall. is a well-known medicinal plant used among Mishmi and other tribes of Arunachal Pradesh for health problems like loose motion, stomach pain, diarrhoea and malaria. This endemic and threatened medicinal plant contains numbers of biologically active compounds and need in-situ as well as ex-situ conservation.

Key words: Mishmi tribe, Medicinal plant, Threatened, Phytoconstituents, Eastern Himalayas, Berberine.
\end{abstract}

\section{INTRODUCTION}

Nature has endowed plant kingdom to the blue planet and plant is one among pre-requisite life supporting system. Plant provides almost everything that man needed and the environment around has been influencing the man's culture since antiquity to make use of available resources around him. Therefore, Man must have learnt use of medicinal plant subject to the hungry, accident, injury, bite of insects or serpent or death of fellow men and made man's instinct by luck or observation to get help from available surroundings ${ }^{1}$ thus the importance of plants and animals was realized by the early men since the dawn of time. They started to use fruits, leaves and tubers for food and medicine. Such experiences became a knowledge system and assimilated as an integral part of man culture that passed down generation after generation and climaxed into traditional knowledge system. ${ }^{2}$ Therefore, Knowledge on the therapeutic and nutritional properties of medicinal herbs and food plants predated recorded history. ${ }^{3}$ Likewise, there are several historical indications that claim the ancient use of natural remedies to resolve primary health problems in different part of the world. ${ }^{1,4,5}$ In fact, traditional medicine practice is as old as mountains and hills in a tribal society where primary health care is totally based on traditional medicines. ${ }^{2}$ With the emerging worldwide interest in adopting and studying traditional systems and exploring their potential based on different health care systems, the evaluation of rich heritage of traditional medicine is essential. ${ }^{6}$

Moreover, in more recent past, the use of plants as medicines has involved the isolation of active compounds, beginning with the isolation of morphine from the opium in the early $19^{\text {th }}$ century. ${ }^{7}$ Drug analysis from medicinal plants led to the isolation of important drugs like cocaine, codeine, digitoxin, and quinine. ${ }^{8}$

As cited above, Indigenous people of Arunachal Pradesh also has predated knowledge on medicinal plants and their uses. But no written records is exist in this part of territory however still exists in form of traditional knowledge and need to record before it is lost forever. It was the Britishers, who explored flora including their uses among aborigines of Arunachal Pradesh in late Nineteenth Century. Mishmi teeta is one among the herbal treasure grows in Arunachal Pradesh. Coptis teeta has been reported only from Indian Territory of Arunachal Pradesh and Yunnan province of China. This herb grows at the lower elevation limit of $1700 \mathrm{mts}$ and upper elevation limit of 2800 mts. This herb is enlisted in Red List Category as endangered (A2cd ver 3.1) (IUCN Red List of threaneted species). The combined effects of unregulated collection and degradation of forest over the

Cite this article: Payum T. Distribution, Ethnobotany, Pharmacognosy and Phytoconstituents of Coptis teeta Wall.: A Highly Valued and Threatened Medicinal Plant of Eastern Himalayas. Pharmacog J. 2017;9(6)Suppl:s28-s34. 
last decade years has resulted in decline of the population of over $60 \%$. Therefore, the species has been assessed as Endangered. About $90 \%$ C. teeta population is in India, therefore considered representative of that of the global population. ${ }^{9}$

This herb was recorded as early as 1825 by R. Wilcox and Captain Bedford followed by Griffith in 1836 from Mishmi Hills of Indian flora. Mishmis and other tribes of Arunachal Pradesh used C. teeta to treat malaria, stomach ache and dysentery. The current rate of Coptis teeta is about Rs. $2000 / \mathrm{kg}$, it is found to be adulterated with the rootstock of Geranium wallichianum D. Don ex Sweet, root of Thalictrum filiolosum DC, roots of Swertia genus resembles the of rhizome of C. teeta. ${ }^{10}$

In the word of Philipson, ${ }^{11}$ herbal medicines are, of course, used for their reputed beneficial effects, however, scientific studies for validation are also important and Pharmacognosy is one of the basic methods to characterize and validate the drugs of natural origin to give correct and authentic identity. Plants provide a great challenge in metabolomics due to the rich chemical diversity of metabolites that they possess across a huge range of concentrations; estimates of 100000-200000 metabolites have been made for the plant kingdom, ${ }^{12}$ And Gas ChromatographyMass Spectrometry (GC-MS) is a hyphenated analytical technique that combines the separation properties of gas-liquid chromatography with the detection feature of mass spectrometry to identify different substances within a test sample. ${ }^{13}$ Gas chromatography-mass spectrometry (GC-MS) is the most commonly used technique for the analysis of liposoluble constituents, especially volatile/semi-volatile compounds, and their metabolites in biological fluids due to its high resolution, selectivity and sensitivity. ${ }^{14}$ Hence, the present study has been taken up to study phytocompounds present in the Mishmi teeta by using GC-MS and pharmacognostic parameters of Coptis teeta.

\section{MATERIALS AND METHODS}

\section{Plant material}

Coptis teeta is a stem less herbaceous plant of Ranunculceae family, much used in Bengal and elsewhere as recorded by Kanjilal, ${ }^{15}$ the roots are gathered towards the end of the rainy season and are carried in tiny little wicker baskets to Sadiya where dealers from other provinces go to buy them. ${ }^{13}$ This herb is perennial herb, rhizomatous with densely fibrous roots, petiole is long, leaves are ovate - lanceolate, flowers are whitishyellow bloom in the month of Feb'- April and rhizome is golden in colour and bitter in taste Figure 1 and 2.

\section{Pharmacognostic studies}

For pharmacognostic works, fresh rhizome was collected from Hawaii forest by Miss Amina Miso of BSc- Botany major Vth semester student of J.N.College, Pasighat. Characterization of pharmacognostic parameters were carried out by following methods given in Shah and Seth. ${ }^{16}$ Kakote et al. ${ }^{17}$ Wallis. ${ }^{18}$

\section{Preparation of extract}

The dry rhizome of Coptis teeta was collected from Anini by Y. Jamoh Lego (a local healer) of Arunachal Pradesh. The sample was shade dried and pulverized to powder using a mechanical grinder. $500 \mathrm{~g}$ of plant powder of the sample was soaked in ethanol for $72 \mathrm{~h}$ with intermittent shaking then filtered through Whit man No. 41 filter paper and concentrated under reduced pressure at $40^{\circ} \mathrm{C}$ using rotary evaporator to obtain a viscous semi solid mass/extract.

\section{GC-MS Analysis}

Gas-Chromatography Mass Specrometry (GC-MS) analysis of the ethanol extracts of Mussaendamacrophyllawas carried out in Shimadzu GCMS-QP-2010 plus system. RTx-5 Sil MS column $(30 \mathrm{~m} \times 0.25 \mathrm{~mm}$ id

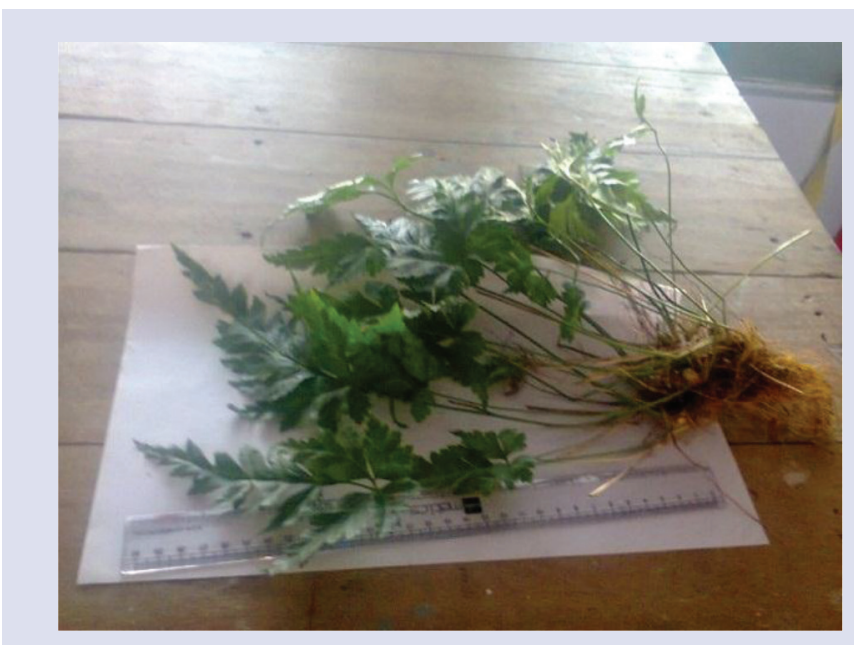

Figure 1: Coptis teeta.

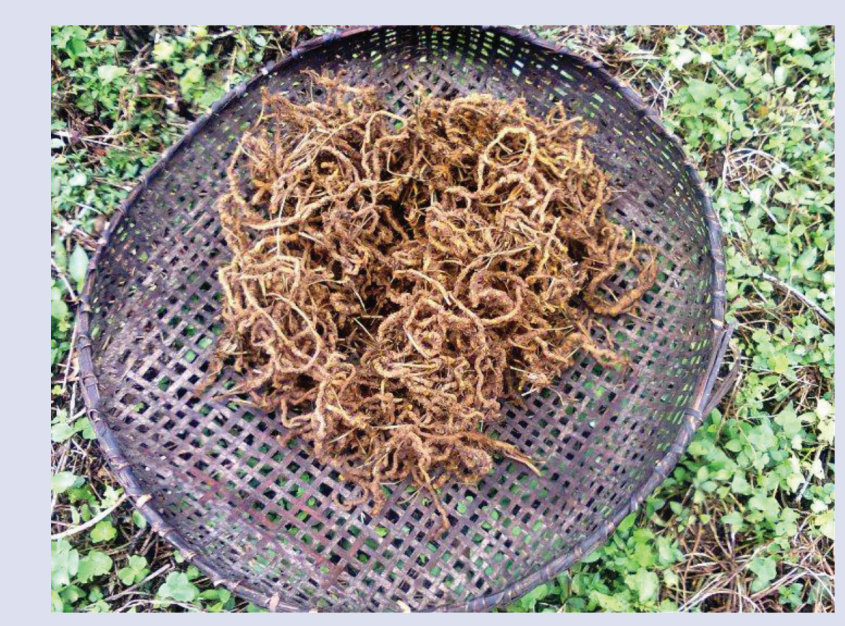

Figure 2: Dried rhizome.

$\times 0.25$ film thickness) was used for the analysis. The operating conditions of the column were as follows:

Oven temperature program from $80^{\circ} \mathrm{C}$ to $210^{\circ} \mathrm{C}$ at $4^{\circ} \mathrm{C} / \mathrm{min}$ withhold time of $2 \mathrm{~min}$ and from $210^{\circ} \mathrm{C}$ to $300^{\circ} \mathrm{C}$ at $15^{\circ} \mathrm{C} / \mathrm{min}$ withhold time of 5 $\mathrm{min}$, and the final temperature was kept for $20 \mathrm{~min}$. The injector temperature was maintained at $270^{\circ} \mathrm{C}$, the volume of injected sample was $0.3 \mu \mathrm{l}$; pressure $85.4 \mathrm{kPa}$, total flow $76.8 \mathrm{~mL} / \mathrm{min}$, column flow $1.21 \mathrm{~mL} / \mathrm{min}$, linear velocity $40.5 \mathrm{~cm} / \mathrm{sec}$, purge flow $3.0 \mathrm{~mL} / \mathrm{min}$, split ratio: 60.0 ; ion source temperature $230^{\circ} \mathrm{C}$; scan mass range of $\mathrm{m} / \mathrm{z} 40-600$ and interface line temperature $280^{\circ} \mathrm{C}$. The identification of compounds was performed by comparing their mass spectra with data from NIST 11 (National Institute of Standards and Technology, US) and WILEY 8.

\section{Identification of phytocompositions}

The identification of compounds was performed by comparing their mass spectra with data from NIST 11 (National Institute of Standards and Technology, US) and WILEY 8. 


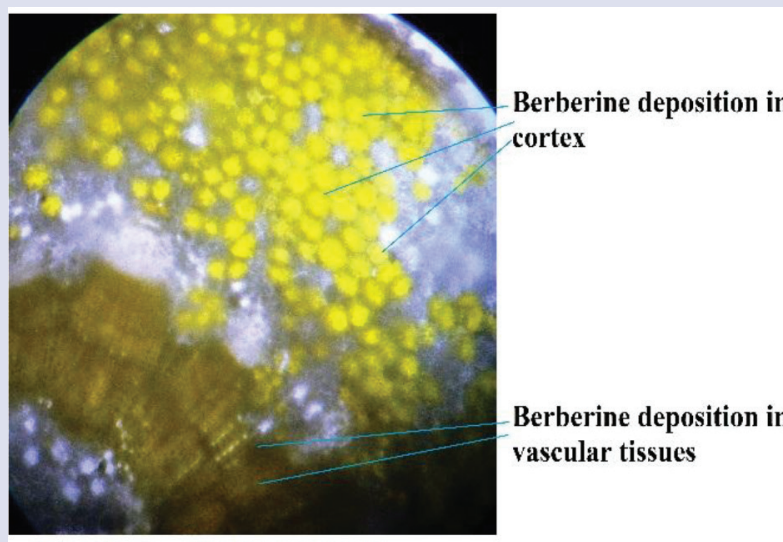

T.S of C. teeta (without stain)

Figure 3: T.S of rhizome shows alkaloid deposition in Parenchymatous tissues.

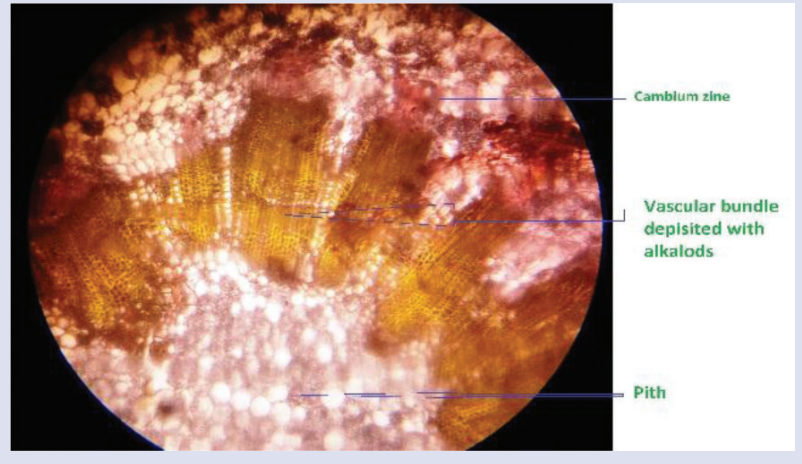

Figure 4: T.S of rhizome shows alkaloids deposition in vascular bundles.

\section{RESULTS}

\section{Ethnobotany, distribution and threatening status}

Mishmis and other tribes of Arunachal Pradesh use C.teeta in case of health problems like malaria, stomach ache, dysentery, Cold and Cough, Diarrhea, blood Dysentery, Typhoid, High blood pressure, Jaundice and to bring down body temperature during fever and also to relieve pain of eyes conjunctives. The rhizome is uprooted manually, hairs of rhizome are cleared, washed, sundried Figure 2 and grinded, soak in water then filtered and stored. In the word of Kanjilal and Borthakur. ${ }^{15}$ Rhizome were brought in tiny little wicker baskets to Sadiya (Assam) where dealers from other Provinces go to buy them. Mishmis bartered M. teeta for opium with Meyor, an ethnic Tibetan tribe, now Arunachali after 1988. ${ }^{19}$ They also brought the Yunnan Chinese silver. ${ }^{20}$ Idu mishmi (Chulikatiya maanu) exchanged daos, musks, ornaments and salt for Coptis teeta with Assamese. ${ }^{21}$ The open selling is illegal, but one can purchase at about Rs.2000/kg if source or seller can be located.

\section{Dose and Preparation}

The rhizome is up rooted; the uprooted rhizome is washed thoroughly in running water and dried under the sunlight (in case of immediate need, dried over the fire place). Dried rhizomes are either cut into pieces or grinded into powder form. These pieces or powder is soak in water (cold/ lukewarm) for at least $30 \mathrm{~min}$ or until the solution appears yellow. For faster result the latter is recommended. The best way to avail its benefit is to consume the decoction twice a day before food.

\section{Pharmacognostic studies}

The rhizome is rough, live or fresh rhizome appears golden yellowish in colour while it looks brownish in dry; leaf scar is prominent and gives rhizome a rough and almost un-straight shape. Root stock profusely originate from the points where leaves developed and less profuse on underground rhizome part. The outermost surface of the transverse sectioned rhizome is covered with multi-layered cork upon cell wall; tissues are well differentiated into cortex, vascular bundles and pith. Alkaloids are chiefly deposited at cortex and Vascular bundles. Parenchymatous and conducting tissues are deposited with full of yellowish alkaloids while hardly any alkaloid deposition on pith Figure 3 and 4 .

The powder studies of the rhizome show dull yellow powder, bitter on taste with total ash of at least $3.7 \%$, acid insoluble $0.8 \%$, ethanol soluble extract of at least $15 \%$ and water-soluble extract weigh $11 \%$ Table 1.

When powder was treated with different chemicals and observed under normal light and ultraviolet light following results were recorded. Powder as such was yellow in day light while it was bright yellow under UV light; dark brown in day light when treated powder with Sodium hydroxide but it appears dark green under UV light; powder was light red in day light when treated with acetic acid while it appears light green under UV light; powder was light brown in day light when treated with nitric acid in day light but it was light green under UV light; dark brown colour appeared in day light when treated with sulfuric acid but it was deep green when observed under UV light. Powder was turmeric colour in day light when treated with hydrochloric acid but dark green in UV light and the powder was brown in day light when treated with ferric chloride while it was dark green under UV light Table 2.

\section{DISCUSSION}

Coptis teeta is a an endemic and highly threatened medicinal plant, this herb is uprooted to collect the rhizome for medicinal purposes and put high pressure on their population, various methods to propagate shows partial success, protection and in situ conservation to increase population is important and further research on the line of pharmaceutical domain should be carried out to bring this useful herb to fight various health problems.

\section{PHYTOCONSTITUENTS}

A total of 56 compounds have been identified from the studied sample Table 3 and 5. Berbine, 13,13a-didehydro-9,10-dimethoxy2,3-(methylenedioxy)- was found to cover highest areas in TIC peak report with the percentage of $41.08 \%$ as given in Table 4 . Other compounds like Deoxyaniflorine (17.04\%), Indeno[1,2-b] quinoxalin-11-one, 2-methyl(5.53\%), Hexadecanoic Acid, Methyl Ester. (5.45 \%), 1,1'-Biphenyl, 3,3'4,4,5,5'-hexamethoxy- (5.42\%), 9,12-Octadecadienoic acid (Z,Z)-, Methyl Ester (4.92 \%), Stigmast-5-EN-3-OL, (3.BETA.)-, (1.90 \%),

Table 1: C. teeta ash contents.

\begin{tabular}{cc}
\hline Parameter & Not less than (\%) \\
\hline Total ash & 3.7 \\
Acid insoluble & 0.8 \\
Ethanol soluble extractive & 15 \\
Water soluble extractive & 11 \\
\hline
\end{tabular}




\section{Table 2: Florescence studies of C.teeta powder}

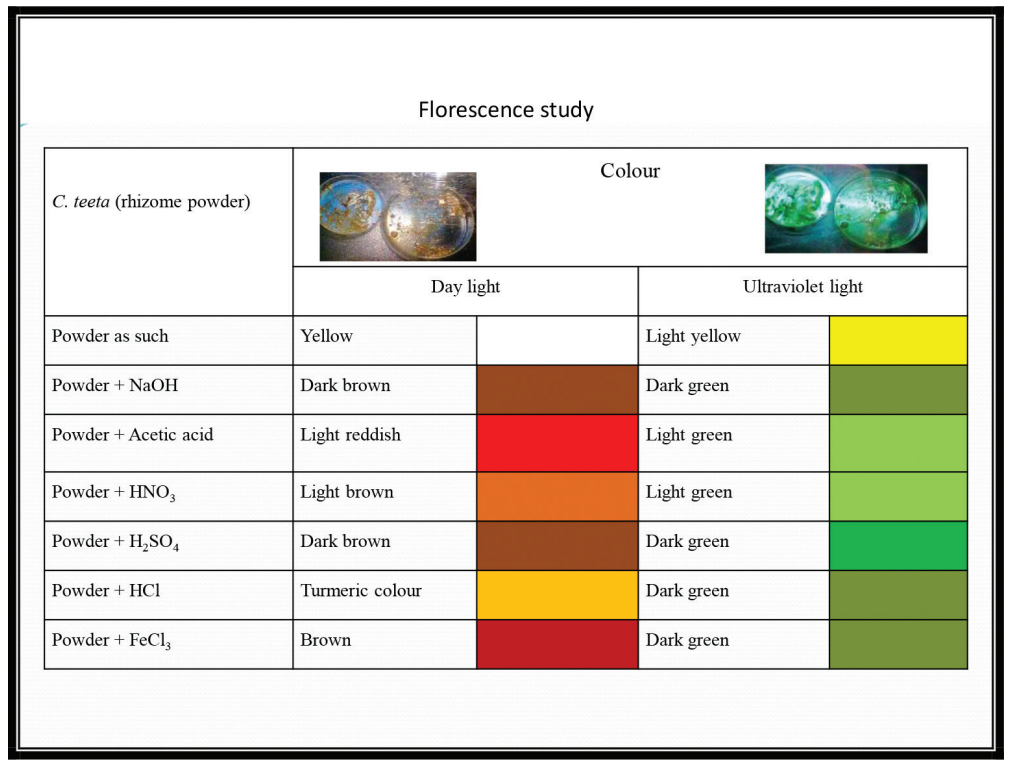

Table 3: Compound table of C.teeta rhizome (ethanolic extract)

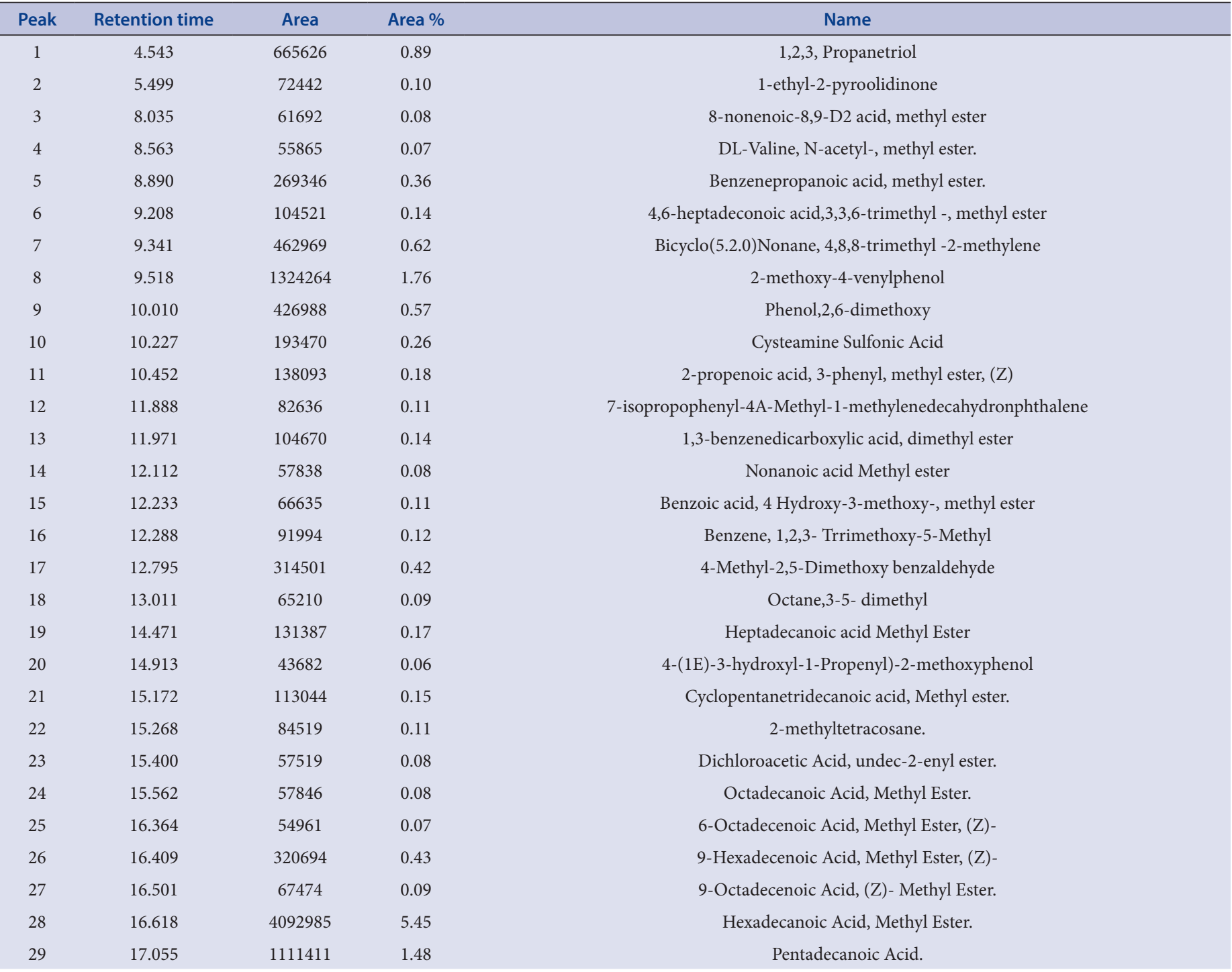

Continued... 


\section{Table 3: Cont'd.}

\begin{tabular}{|c|c|c|c|c|}
\hline 30 & 17.381 & 139026 & 0.18 & Cyclopropanenonanoic acid, 2-[(2-butylcyclopropyl) Methyl] \\
\hline 31 & 17.593 & 324315 & 0.43 & Hexadecanoic acid, 15-Methyl-, Methyl Ester. \\
\hline 32 & 17.833 & 58432 & 0.08 & Hexadecane-1, 16-diol. \\
\hline 33 & 18.093 & 39891 & 0.05 & Noroxyhydrastinine \\
\hline 34 & 18.184 & 907073 & 1.21 & n-Nonadecanol-1 \\
\hline 35 & 18.296 & 3699241 & 4.92 & 9,12-Octadecadienoic acid (Z,Z)-, Methyl Ester. \\
\hline 36 & 18.359 & 1105031 & 1.47 & 9,12,15-Octadecatrienoic acid, Methyl Ester(Z,Z,Z)- \\
\hline 37 & 18.543 & 982364 & 1.31 & Methyl Streate \\
\hline 38 & 19.121 & 244706 & 0.33 & (9E,12E)-9,12 Octadecadienoyl Chloride \\
\hline 39 & 20.513 & 130030 & 0.17 & Eicosanoic Acid, Methyl Ester. \\
\hline 40 & 20.600 & 170007 & 0.23 & Trans-2-Pinanol \\
\hline 41 & 20.750 & 149081 & 0.20 & 7-hydroxy, 6-methyl-bicyclo[4.3.0] nona-3-one \\
\hline 42 & 23.310 & 125676 & 0.17 & Tetracosanoic acid, Methyl Ester \\
\hline 43 & 25.068 & 73666 & 0.10 & Methyl Lignocerate \\
\hline 44 & 26.523 & 118431 & 0.16 & Lignoceric Acid Methyl Ester \\
\hline 45 & 29.644 & 224927 & 0.30 & 1,2-Dimethoxy-4-[(1E)-1-Prophenyl]Benzene \\
\hline 46 & 30.986 & 470208 & 0.63 & Canadine \\
\hline 47 & 31.871 & 4074513 & 5.42 & 1,1'-Biphenyl, 3,3',4,4,5,5'-hexamethoxy- \\
\hline 48 & 33.343 & 104062 & 0.14 & alpha.-Tocopherol-.beta.-D-mannoside \\
\hline 49 & 34.365 & 543208 & 0.72 & 3,4-Quinolinedicarboxylic acid, 6-Methoxy-2-Phenyl-, Dimethyl ester \\
\hline 50 & 35.011 & 141443 & 0.19 & $\mathrm{~N}$-(2,5-Di-Tertbutylphenyl)Phthalimide \\
\hline 51 & 36.745 & 31403799 & 41.78 & Berbine, 13,13a-didehydro-9,10-dimethoxy-2,3-(methylenedioxy)- \\
\hline 52 & 36.745 & 4159109 & 5.53 & Indeno[1,2-b]quinoxalin-11-one, 2-methyl- \\
\hline 53 & 37.631 & 616698 & 0.82 & $\begin{array}{c}\text { C-Chloro-N-[2-(6,7-Dimethoxy-Isoquinolin-1-YLMethyl)-4,5-Dimethoxy-Phenyl]- } \\
\text { Methanesulfonamide }\end{array}$ \\
\hline 54 & 38.576 & 1427579 & 1.90 & Stigmast-5-EN-3-OL, (3.BETA.)- \\
\hline 55 & 40.435 & 12810590 & 17.04 & Deoxyaniflorine \\
\hline \multirow[t]{2}{*}{56} & 43.321 & 220680 & 0.29 & Cholest-4-en-3-one \\
\hline & & 75158068 & 100.00 & \\
\hline
\end{tabular}

\section{Table 4: Compound activity}

\begin{tabular}{|c|c|c|c|c|}
\hline Peak No. & Area \% & Name & Compound type & Activity \\
\hline 8 & 1.76 & 2-methoxy-4-venylphenol & Phenolic & Anti tumour ${ }^{22}$, Antimicrobial Anti-inflammatory ${ }^{23}$. \\
\hline 28 & 5.45 & $\begin{array}{l}\text { Hexadecanoic Acid, Methyl } \\
\text { Ester. }\end{array}$ & Palmitic acid methyl ester & $\begin{array}{c}\text { Antioxidant, Hypocholesterolemic, Nematicide, Pesticide, Antiandrogenic } \\
\text { flavor, Hemolytic,5-Alpha reductase inhibitor*. }\end{array}$ \\
\hline 29 & 1.48 & Pentadecanoic Acid. & Palmitic acid methyl ester & Antioxidant ${ }^{*}$. \\
\hline 34 & 1.21 & n-Nonadecanol-1 & Alcoholic compound & Anti-microbial ${ }^{24}$. \\
\hline 36 & 1.47 & $\begin{array}{l}\text { 9,12,15-Octadecatrienoic } \\
\text { acid, Methyl Ester(Z,Z,Z)- }\end{array}$ & Linolenic acid ester & $\begin{array}{l}\text { Antiinflammatory, Hypocholesterolemic, Cancer preventive, Hepatoprotective, } \\
\text { Nematicide Insectifuge, Antihistaminic, Antieczemic, Antiacne, 5-Alpha } \\
\text { reductase inhibitor Antiandrogenic, Antiarthritic, Anticoronary, Insectifuge }\end{array}$ \\
\hline 37 & 1.31 & Methyl Streate & Fatty acid methyl esters & Anti-diarrheal ${ }^{25}$. \\
\hline 51 & 41.78 & Berberine & Alkaloids & Antitumour ${ }^{26,}$ analgesic, Anesthetic, antibacterial ${ }^{*}$. \\
\hline 54 & 1.90 & $\begin{array}{l}\text { Stigmast-5-EN-3-OL, } \\
\text { (3.BETA.)- }\end{array}$ & Phytosterols & Potent anti-diabetic agent in regulating glucose transport ${ }^{28}$. \\
\hline \multicolumn{5}{|c|}{ https://phytochem.nal.usda.gov/phytochem/chemicals/show/14192?et= } \\
\hline
\end{tabular}


Table 5: Chromatogram of C.teeta rhizome (ethanolic extract).

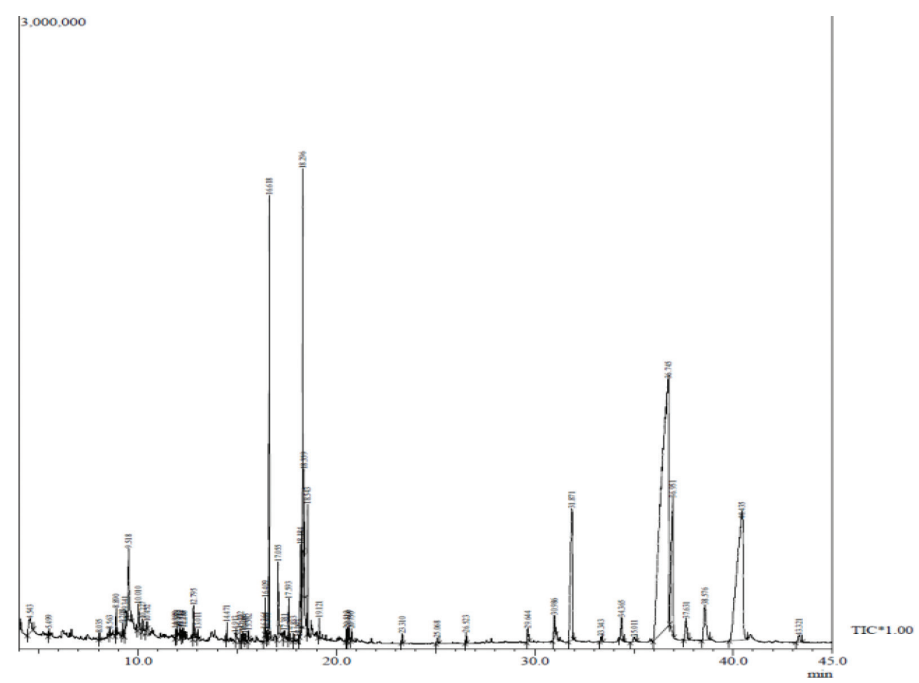

2-methoxy-4-venylphenol (1.76\%), Pentadecanoic Acid (1.48\%), 9,12,15-Octadecatrienoic acid, Methyl Ester (Z,Z,Z)- (1.47\%), Methyl Streate (1.31 \%), n-Nonadecanol-1 (1.21 \%), Phenol,2,6-dimethoxy $(0.57 \%)$ respectively.

Phenolic, Palmitic acid methyl ester, Trans linoleic acid, Linolenic acid ester, Fatty acid methyl esters, Protoberberine alkaloids, spiroindeno quinoxaline, Phytosterols and alkaloids were the major compounds that has been reported to be biologically active from the studied sample Table 4. Coptis teeta contain compounds reported for activities like Anti tumour, Antimicrobial, Anti-inflammatory, Antioxidant, Hypocholesterolaemia, Nematicide, Pesticide, Antiandrogenic, flavor, Hemolytic, 5-Alpha reductase inhibitor, Hepatoprotective, antihistaminic, hypocholesterolaemia, antieczemic, Hypocholesterolaemia, Cancer preventive, Antihistaminic, Antieczemic, Antiacne, 5-Alpha reductase inhibitor, Antiandrogenic, Antiarthritic, Anti-coronary, Anti-diarrheal Anti cell proliferation of tumour cell, Potent anti-diabetic agent in regulating glucose transport as given in Table 4 .

\section{CONCLUSION}

It is concluded that Coptis teeta is distributed in the eastern Himalayas and a highly threatened important medicinal plant. The study gives hints that Coptis teeta contain at least 56 compounds, out of which ten compounds are biologically active against numbers of health problems like anti-cancer and anti-diarrhea. It is important to make out that the traditional use among the tribal people of Arunachal Pradesh for various health problems like anti-diarrhea, stomach pain and to bring down the temperature of fever could be correlated with the reported compounds present and found in this study; 2-methoxy-4-venylphenol as Antitumour. $^{22}$ Antimicrobial Anti-inflammatory ${ }^{23}$ likewise Methyl Streate has already been reported as antidiarrheal. ${ }^{25}$ Therefore, it is concluded that Coptis teeta need protection, propagation and further studies for the welfare of ecosystem and mankind.

\section{ACKNOWLEDGEMENT}

The author acknowledge O. Miso, G. Ering, M. Langkam, A. Tayang of BSc. final year Botany major students of J.N. College, Pasighat for their laboratory assistance, Mrs Y.J Lego, a local healer for materials and Dr. A Kumar, AIRF, JNU, New Delhi for GC-MS work.

\section{CONFLICT OF INTEREST}

The authors declare no conflict of interest.

\section{ABBREVIATION USED}

C.teeta: Coptis teeta Wall; GCMS: Gas Chromatograpy Mass Spectrometry.

\section{REFERENCES}

1. De Pasquale A. Pharmacognosy: The oldest modern science. Journal of Ethnopharmacology. 1984;11(1):1-6.

2. Payum T, et al. 99 Selected Folk Medicinal Plants of East Siang District of Arunachal Pradesh, India. Am J Pharm Tech Res. 2015;5(1):399-409.

3. Breemen RV, Fong HHS, Farnsworth NR. Ensuring the safety of botanical dietary supplements. American Journal of Clinical Nutrition. 2008;87(2):509S-13.

4. Gurib-Fakim A. Medicinal Plants: Traditions of yesterday and drugs of tomorrow. Molecular Aspects of Medicine. 2006;27(1):1-93.

5. Balunas MJ, Kinghorn AD. Drug discovery from medicinal plants. Life Sciences. 2005;78(5):431-41.

6. Mukheerje P. Evaluation of Indian Traditional Medicine: Drug Information Journal. $2001 ; 35(2): 623-32$.

7. Kinghorn AD. Pharmacognosy in the $21^{\text {st }}$ century. journal of Pharmacy and Pharmacology. 2001;53(2):135-48.

8. Butlet MS. The role of natural product chemistry in drug discovery. Journal of Natural products. 2004;67(12):2141-53.

9. http://www.iucnredlist.org/details/50126583/0

10. Selvam ABD. Pharmacognosy of Negative Listed Plants. Botanical survey of India, Kolkata. 2012;26-36.

11. Phillipson JD. Phytochemistry and Pharmacognosy. Phytochemistry. 2007 68(22):2960-72.

12. Oksman-Caldentey KM, Inzé D. Plant cell factories in the post-genomics era: new ways to produce designer secondary metabolites. Trends Plant Sci. 2004;9(9):433-40.

13. Chauhan A, Goyal MK, Chauhan P. GC-MS Technique and its Analytical Applications in Science and Technology. J Anal Bioanalytical Tech. 2014;5(6):222. doi: 10.4172/2155-9872.1000222.

14. Ye Jiesheng. Application of gas chromatography-mass spectrometry in research of traditional Chinese medicine: Chemical Papers. 2009;63(5):506-11.

15. Kanjilal and Borthakur: Flora of Assam: (1997 reprint); Omsons Publications, New Delhi. 1997;1:9. 1100270.

16. Shah B, Seth AK. Textbook of Pharmacognosy and Phytochemistry. Reed Elsevier India Private Lomited, New Delhi. 2010;110019.

17. Kokate CK, Purohit AP, Gokhale SB. Pharmacognosy. 2012;1:(47 th edn) Nirala Prakshan; Pune. 411005, 6.22.

18. Wallis TE. Practical Pharmacognosy. Pharma Med Press, sultan Bazar, Hyderabad. 2011;500095

19. Williamson N. The Lohit- Brahmaputra between Assam and South-Eastern Tibet, November 1907-January 1908. The Geographical Journal. 1909;34(4):363-83.

20. Aiyadurai A. Meyors of Arunachal Pradesh. The Eastern Anthropologist. 2011;64(4):459469.

21. Bisht NS, Bankoti TS. Encyclopaedic Ethnography of the Himalayan Tribes. 2004; Global vision Publishing House, Delhi 110093.

22. Jeong JB, Jeong HJ. 2-Methoxy-4-vinylphenol can induce cell cycle arrest by blocking the hyper-phosphorylation of retinoblastoma protein in benzo[a]pyrenetreated NIH3T3 cells Biochemical and Biophysical Research Communications. 2010: 752-7.

23. Jeong JB, Hong SC. Jeong HJ, Koo JS. Anti-inflammatory Effect of 2-Methoxy4-Vinylphenol via the Suppression of NF-KB and MAPK Activation, and Acetylation of Histone H3; Arch Pharm Res. 2011;34(12):2109-16.

24. Dalli AK, Saha G, Chakraborty U: Characterization of Antimicrobial compounds from a common fern, Pterin biaurita. Indian J Exp Biol. 2007;5:285-290.

25. Andrea M, Nascimento, Raphael Conti et al. Bioactive extracts and chemical constituents of two endophytic strains of Fusarium oxysporum. Brazilian Journal of Pharmacognosy. 2012;22(6):1276-81.

26. Sun Y, Xun K, Wang Y, Chen Z: Anti-Cancer Drugs. 2009;20(9):757-69.

27. Gazit A, App H, McMohan G et al. Tyrphostins 5. Potent Inhibitors of PlateletDerived Growth Factor Receptor Tyrosine Kinase: Structure-Activity Relationships in Quinoxalines, Quinolines, and Indole Tyrphostins. Journal of Medicinal Chemistry. 1996;39(11):2170-7.

28. Sujatha S, Anand S, Sangeetha KN Shilpa K et al. Biological evaluation of (3ß)-STIGMAST-5-EN-3-OL as potent anti-diabetic agent in regulating glucose transport using in vitro model. International Journal of Diabetes Mellitus. 2010;2(2):101-9 
GRAPHICAL ABSTRACT

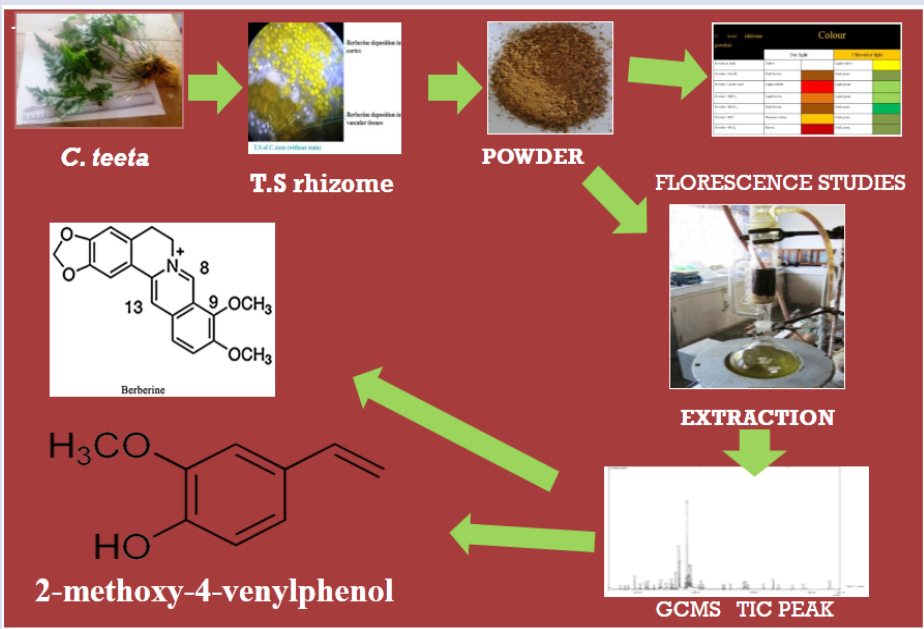

ABOUT AUTHORS

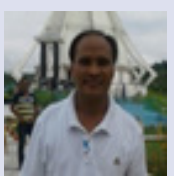

Temin Payum obtained his Ph.D degree in 2015 from Rajiv Gandhi University, Itanagar. Currently he is working as Assistant Professor at Jawaharlal Nehru College, Pasighat, Department of Botany, Arunachal Pradesh, India. He works on Ethnobotany and Medicinal Food, Anti oxidants, Proximate, Pharmacognosy and Phytochemisty on the medicinal food plants used among Tribal people of Arunachal Pradesh.

Cite this article: Payum T. Distribution, Ethnobotany, Pharmacognosy and Phytoconstitents of Coptis Teeta Wall.: A Highly Valued and Threatened Medicinal Plant of Eastern Himalayas. Pharmacog J. 2017;9(6)Suppl:s28-s34. 